\title{
Transport Nutrien penyebab Eutrofikasi dari Daerah Tangkapan Air Waduk Mrica Banajrnegara
}

\author{
A.S. Piranti' ${ }^{1}$, Soedarmadji', G.Waluyo ${ }^{3}$, Suwardi ${ }^{4}$ \\ ${ }^{1}$ Fak. Biologi Unsoed, Purwokerto, ${ }^{2}$ Fak. Geografi UGM Yogyakarta, ${ }^{3}$ Fak. Sains dan Teknik \\ Unsoed, Purwokerto, ${ }^{4}$ Fak. Pertanian Unsoed Purwokerto \\ e-mail : agatha.piranti@gmail.com; sudarmadji@geo.ugm.ac.id; gentur,geologi@gmail.com
}

\begin{abstract}
The transport of nutrien causing eutrophication in water from catchment area especially fosforus (P) through runoff is determined by type of landuses, slop, soils type, and land cover (Jeje,2006). The research was conducted using a survey method. The sampling technique was done by a purposive sampling on any flooding in the rivers that pass through areas with specific land use (settlement, forest, plantations, agricultural fields and rice field). The main parameters were river discharge and the content of nutrients causing eutrophication that was phosphorus $(P)$ in rivers. The $P$ loadingfrom cacthment area to Mrica reservoir was $11,526,706.14 \mathrm{~kg} / \mathrm{year}$ and the load allocation (LA) was 3,833,587.70 kg/year. The reservoir operational of power generating dan flushing activity were able to manage the LA up to $1,147,329.09 \mathrm{~kg} / \mathrm{year}$, so the TMDL of Mrica reservoir become 4,980,916.78kg/year. It was concluded that the highest transport of $\mathrm{P}$ was from paddy field and then followed by respectivelly agricultural (potato) field, plantation (perhutani) field, settlement area, and forest area.
\end{abstract}

Keywords: Coefficient export, phosphorus, catchment area, eutrophication, landuse

\begin{abstract}
Abstrak
Besarnya transport nutrien dari daerah tangkapan air (DTA) terutama fosfor $(P)$ yang terbawa oleh run off tergantung pada karakteristik lahan yang meliputi jenis penggunaan lahan, kelerengan, jenis tanah, dan jenis tanaman penutup (Jeje, 2006). Penelitian ini dilakukan menggunakan metode survei. Teknik pengambilan sampel dilakukan secara purposive pada setiap terjadi banjir di sungai-sungai yang melewati area dengan penggunaan lahan tertentu (pemukiman, hutan, perkebunan, tegalan dan sawah). Parameter utama adalah $\mathrm{P}$ total di sungai dan debit sungai.Parameter pendukungnya adalah karakteristik lahan yang meliputi land cover, kelerengan, curah hujan, kapasitas lapang dan karakteristik tanah (jenis tanah, kandungan $\mathrm{N} \& \mathrm{P}$ tanah, dan retensi tanah), dan jumlah penggunaan pupuk. Total loading $\mathrm{P}$ dari DTA ke waduk Mrica sebesar 11,526,706.14 kg/tahun dan beban nutrien (Load Allocation/LA) yang masuk ke waduk Mrica sebesar 3,833,587.70 kg/tahun. Dari LA yang masuk ke waduk tersebut sebanyak $1,147,329.09 \mathrm{~kg} / \mathrm{tahun}$ telah mampu dikelola melalui kegiatan operasi waduk sebagai PLTA dan flushing. Maka TMDL waduk Mrica menjadi sebesar 4,980,916.78kg/tahun. Penelitian ini dapat disimpulkan bahwa penggunaan lahan sawah paling tinggi dalam mentransport TP ke waduk, disusul dengan tegalan (lahan kentang), kebun perhutani, pemukiman dan hutan. Pola operasional waduk sebagai PLTA dan kegiatan flushingmampu menurunkan beban nutrien yang masuk ke waduk.
\end{abstract}

Kata kunci : Coefficient export, fosfor, eutrofikasi, daerah tangkapan air, penggunaan lahan

\section{Pendahuluan}

Phosphorus merupakan unsur utama penyebab eutrofikasi danau dan waduk yang berasal dari kegiatan manusia (Hart et al., 2004). Fosfor yang terbawa aliran run off dapat dibedakan berdasarkan bentuk fisiknya, di antaranya dapat berupa fosfat anorganik, organik, partikel ataupun terlarut. Bentuk fosfor terlarut $\left(\mathrm{PO}_{4}\right)$ yang masuk ke waduk dapat langsung dimanfaatkan oleh fitoplankton, sedangkan bentuk partikel fosfat yang terbawa aliran runoff dari lahan pertanian akan diendapkan dan diakumulasikan di sedimen waduk. Apabila lapisan antara sedimen-water interface dalam kondisi anoxic, fosfor akan dilepaskan ke kolom air dalam bentuk terlarut $\left(\mathrm{PO}_{4}{ }^{3+}\right)$ yang dapat digunakan langsung oleh fitoplankton, sehingga sedimen dapat berfungsi sebagai sumber ortofosafat.

Besarnya Ploading dapat dihitung menggunakan coeffisien exportyang dapat 
mencerminkan sejumlah nutrien yang dihasilkan dari area tertentu per unit waktu ( $\mathrm{kg} / \mathrm{ha} /$ tahun) yang dibawa oleh runoff menuju ke sungai dan akhirnya ke waduk (Jeje et al, 2006). Penggunaan coeffisien exportdidasarkan pada asumsi bahwa aktitas landuse tertentu akan menghasilkan sejumlah nutrien tertentu yang masuk ke dalam sistem waduk (McFarland \& Hauck, 2006).Koefisien export nutrien ini dapat digunakan untuk menghitung total $P$ yang masuk ke waduk ( $\mathrm{P}$ load) sehingga selanjutnya dapat ditentukan besarnya total maximum daily loads (TMDL) waduk yang bersangkutan. Selama ini besarnya TMDL untuk waduk dan danau di Indonesia belum pernah dilakukan karena belum ada nilai coefficient export nutrien untuk jenis-jenis penggunaan lahan di Indonesia. Oleh karena itu perlu ditentukan coefficient export nutrien untuk masing-masing jenis penggunaan lahan. Penentuan TMDL waduk selanjutnya dapat digunakan sebagai dasar dalam perencanaan dan penyusunan strategi pengelolaan untuk waduk dan danau yang bersangkutan sehingga dapat mencapai kualitas air sesuai target nutrien kriteria yang telah ditetapkan dan konservasi lahan secara holistik dan berkelanjutan.

\section{Metode Penelitian}

Penelitian ini akan dilaksanakan di waduk Mrica dan di daerah tangkapan air (DTA) Waduk Mrica yang meliputi dua wilayah kabupaten yaitu Wonosobo dan Banjarnegara. Penelitian dilakukan pada bulan Mei - Juli 2010 menggunakan metode survai. Teknik pengambilan sampel dilakukan secara purposive pada setiap terjadi banjir di sungai-sungai yang melewati area dengan penggunaan lahan tertentu (pemukiman, hutan, perkebunan, ladang dan sawah) di masing-masing sub DAS yang ada di kawasan DTA waduk Mrica yaitu Sub DAS Begaluh, Tulis, Serayu Hulu, Mrawu, Serayu Tengah dan Lumajang.

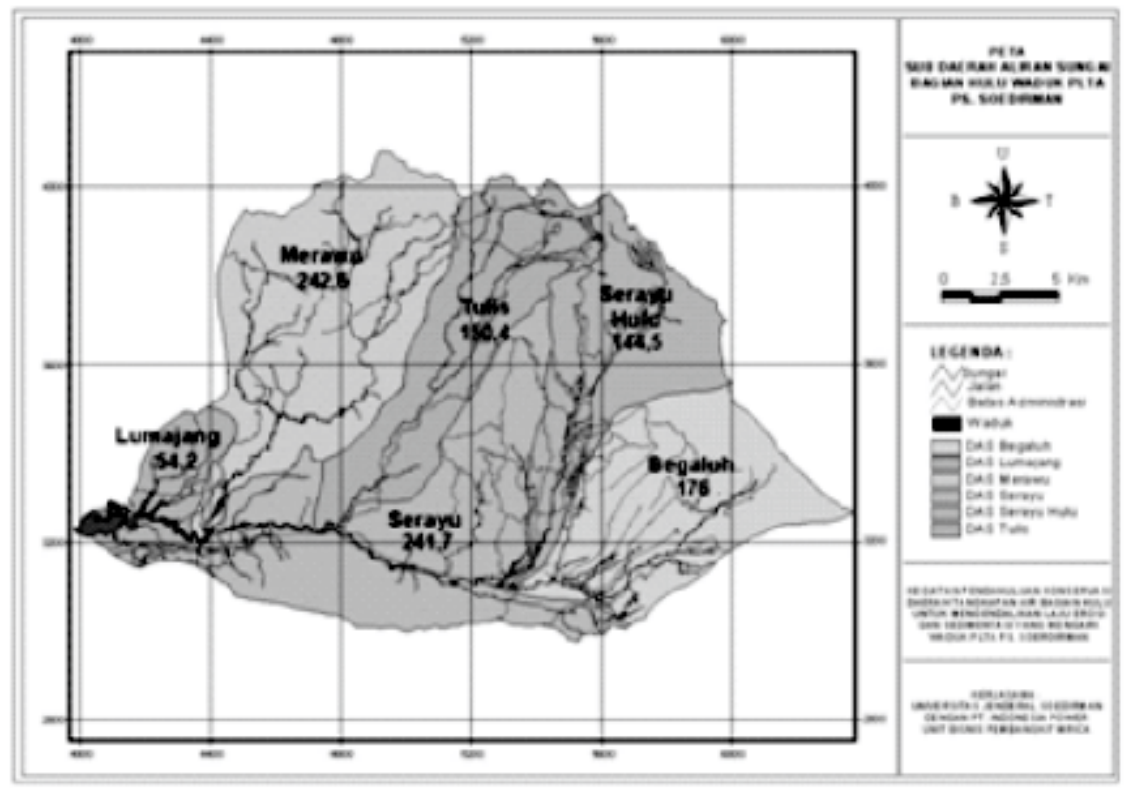

Gambar 1. Wilayah DTA Waduk Mrica

Parameter utama dalam penelitian ini adalah kandungan fosfor $(P)$ di sungai dan debit sungai - sungai dalam area kajian.Parameter pendukungnya adalah karakteristik lahan yang meliputi land cover, kelerengan, curah hujan, kapasitas lapang dan karakteristik tanah (jenis tanah, kandungan $\mathrm{P}$ tanah, dan kemampuan tanah mengikat $P$ /retensi $P$ ), dan jumlah penggunaan pupuk. Penentuan koefisien eksport nutrien dari DTA waduk Mrica sesuai dengan jenis penggunaan lahan dilakukan dengan penghitungan menggunakan rumus : CE $(\mathrm{kg} / \mathrm{ha} / \mathrm{th})=\mathrm{K} \times \mathrm{D} \times \mathrm{L}$ dimana CE (coefficient export masing-masing landuse), $\mathrm{K}$ (konsentrasi nutrien sungai), D (debit sungai), $L$ (Luas area masing-masin landuse). Menghitung $P$ load dan TMDL waduk Mrica menggunakan rumus sebagai berikut :TMDLs = WLA + LA + MOS, dimana 
WLA (Wasteload Allocation/masukan nutrien dari point source), LA (Load Allocation/ masukan nutrien dari non point source) dan MOS (Margin of Safety/secara implisit merupakan perkiraan besarnya polutan nutrien yang telah mampu dikelola dalam program manajemen yang sedang diterapkan).

\section{Hasil dan Pembahasan}

Aktivitas perubahan landscape termasuk perubahan tata guna lahan yang dilaksanakan di daerah hulu DAS tidak hanya akan memberikan dampak di daerah di mana kegiatan tersebut berlangsung, namun juga menimbulkan dampak di daerah hilir dalam bentuk perubahan fluktuasi debit dan transport sedimen serta material terlarut dalam sistem aliran air. Debit aliran sungai merupakan sarana transport SSAS (Suspended Solid and Sediment Yield)dan berbagai jenis hara dari DAS ke dalam sistem waduk dan dapat menyebabkan kontaminasi atau polusi perairan.
Kemampuan bahan polutan tersebut mencapai outlet DAS tergantung dari fisiografi lahan yang meliputi tingkat kelerengan, jenis tanah dan bentuk penggunaan lahan (landuse/ land cover) yang dilalui oleh aliran air permukaan atau run off (McFarland \& Hauck, 2001).

Tanah merupakan hasil kerja dari proses-proses yang dipengaruhi oleh iklim dan organisme pada bahan induk tanah yang terletak pada posisi topografi tertentu selama waktu yang tertentu pula. Dengan demikian pada daerah yang beriklim berbeda akan mempunyai ciri tanah yang berbeda pula. Satuan-satuan tanah yang ada di DTA waduk Mrica adalah kelompok Aluvial, Litosol, Andosol, Latosol, dan Grumusol (Tabel 3). Berdasarkan kemampuan mengikat nutrien $\mathrm{P}$ di DTA waduk Mrica, tanah litosol mampu mengikat nutrien $\mathrm{P}$ yang terkandung dalam tanah paling tinggi (96.4\%) dibandingkan jenis tanah lainnya yaitu andosol ( $86.5 \%)$, alluvial $(72.8 \%)$ dan latosol $(53.1 \%)$ dan paling rendah grumosol (37\%) (Gambar 6).

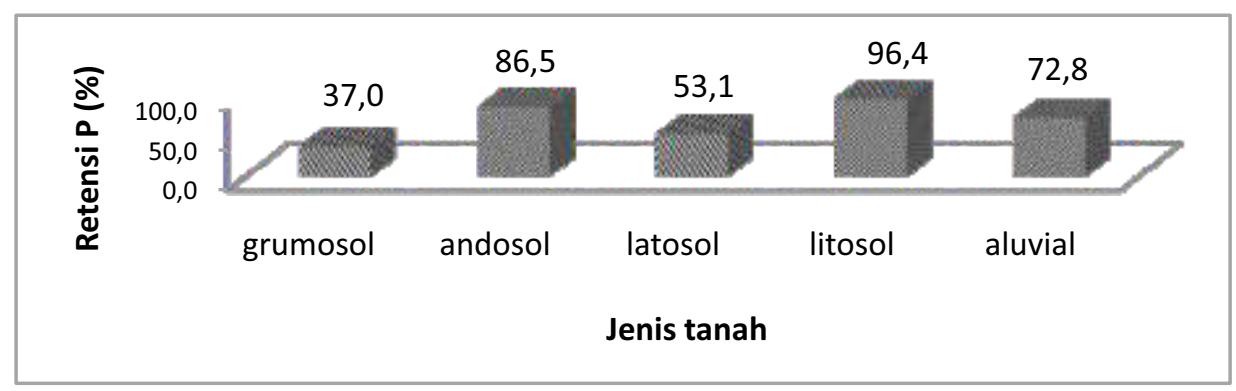

Gambar 6. Retensi tanah di lahan yang ada di DTA waduk Mrica

Luas daerah tangkapan air (DTA) sebesar 100,296.62 hektar yang terdiri atas 6 sub DAS yaitu Begaluh (17,598 ha), Serayu Hulu (13,652.6 ha), Tulis $(15,037.9$ ha), Mrawu (24,215.6 ha), Serayu Tengah $(24,368.6)$ dan Lumajang $(5,423.9$ ha). Jenis tanah yang mendominasi kawasan ini adalah tanah latosol $(38,1 \%)$ dan andosol (36.5 \%). Latosol merupakan tanah yang telah berkembang dibawah pengaruh iklim yang basah dengan membetuk profil tanah yang dalam dan tersebar luas di daerah kajian yang mencakup semua daerah perbukitan dan pegunungan yang tertutup oleh material volkanik. Latosol merupakan tanah yang potensial untuk pengembangan pertanian, namun juga menyimpan potensi erosi yang besar sebagai akibat dari posisinya pada lereng-lereng perbukitan dan pegunungan.

Andosol mempunyai sifat fisik yang spesifik, yaitu berat jenisnya sangat ringan dengan tekstur debuan. Oleh karena BJ yang rendah dan tekstur yang debuan ini, maka Andosol merupakan tanah yang erodible (mudah tererosi). Pemanfaatan tanah Andosol yang kurang hati-hati akan mengakibatkan rusaknya satuan tanah ini dan pada akhirnya membentuk tanah Litosol yang tidak potensial. Grumusol merupakan tanah lempungan yang mempunyai daya kembang kerut tinggi sebagai akibat dari adanya tipe lempung smectite. Lempung tipe ini adalah spesifik terbentuk di bawah iklim tropik. Grumusol berkembang dari sembarang bahan induk yang dapat 
menghasilkan lempung dalam jumlah yang tinggi $(>35 \%)$ dan dibawah suasana basa dimana unsur Ca merajai dalam kompleks pertukaran kationnya. Grumusol merupakan tanah yang cukup potensial untuk pengembangan pertanian apabila kecukupan air. Persebaran Grumusol di daerah kajian terdapat di bagian hilir dari Merawu.

Tabel 3. Luas area masing-masing jenis tanah di tiap sub DAS di DTA waduk Mrica

\begin{tabular}{lrrrrrr}
\hline \multirow{2}{*}{ Sub DAS } & \multicolumn{9}{c}{ Luas area jenis tanah (ha) } & \multirow{2}{*}{ TOTAL (ha) } \\
\cline { 2 - 6 } & grumosol & \multicolumn{1}{c}{ latosol } & \multicolumn{1}{c}{ andosol } & litosol & \multicolumn{1}{c}{ aluvial } & TO \\
\hline Tulis & $1,513.3$ & $3,813.2$ & $9,200.1$ & - & 511.3 & $15,037.9$ \\
Serayu Hulu & - & - & $12,037.2$ & $1,576.5$ & 38.8 & $13,652.6$ \\
Serayu Tengah & 768.5 & $21,096.2$ & $2,504.0$ & - & - & $24,368.6$ \\
Merawu & $3,979.3$ & $9,757.5$ & $10,344.4$ & & 134.4 & $24,215.6$ \\
Lumajang & $1,374.7$ & $3,503.3$ & - & 545.9 & - & $5,423.9$ \\
Begaluh & - & - & $2,517.7$ & $15,063.1$ & 17.2 & $17,598.0$ \\
\hline TOTAL & $\mathbf{7 , 6 3 5 . 7}$ & $\mathbf{3 8 , 1 7 0 . 2}$ & $\mathbf{3 6 , 6 0 3 . 4}$ & $\mathbf{1 7 , 1 8 5 . 5}$ & $\mathbf{7 0 1 . 8}$ & $\mathbf{1 0 0 , 2 9 6 . 6 2}$ \\
\hline Persentase (\%) & $\mathbf{7 . 6}$ & $\mathbf{3 8 . 1}$ & $\mathbf{3 6 . 5}$ & $\mathbf{1 7 . 1}$ & $\mathbf{0 . 7}$ & $\mathbf{1 0 0}$ \\
\hline
\end{tabular}

Kondisi tanahnya yang erodible dan topografi yang berbukit-bukit menyebabkan kemungkinan bahaya longsor dan erosi terjadi di DTA waduk Mrica jika lahannya tidak dikelola dengan baik berdasarkan kaidah-kaidah konservasi lahan dan air. Berdasarkan kajian lapangan di DTA waduk Mrica dan didukung dengan data dari Tim Konservasi PT. Indonesia Power (2006) dan Subagiyo (2008), kondisi lingkungan hutan rakyat/lahan milik rakyat pada daerah perbukitan dengan tingkat kemiringan lebih besar $45^{\circ}$ telah banyak mengalami konversi lahan hutan menjadi areal pertanian tanaman sayuran seperti kentang, kobis dan wortel. Pola tanam terutama kentang yang tidak mengindahkan kaidah konservasi misalnya penanaman yang tidak searah dengan arah kontur tanah, maka hal tersebut akan meningkatkan laju $P$ bersama-sama dengan laju erosi. Struktur tanah di dataran tinggi Dieng (daerah kajian) memiliki top soil yang tebal ( 7-15 meter), terutama di area yang memiliki kemiringan yang tajam sehingga akan mudah mendorong peningkatan laju erosi pada musim hujan. Laju erosi di sub DAS Serayu Hulu mencapai $4.06 \mathrm{~mm} /$ tahun, di sub DAS Mrawu mencapai $10.57 \mathrm{~mm} /$ tahun dan di sub DAS Lumajang mencapai $2.84 \mathrm{~mm} /$ tahun (PT. Indonesia Power, 2007 dan Waluyo, 2008). Dengan besarnya sedimen yang terbawa runoff maka kualitas tanah menjadi menurun karena hilangnya lapisan top soil sehinggapenggunaan pupuk organik maupun anorganik di kawasan Dieng menjadi sangat intensif. Penggunaan pupuk di Sub DAS Mrawu mencapai 5,826.4 kg/ha dan pupuk an organik mencapai 429.7 kg/ha) (Tabel 4 ).

Tabel 4 : Penggunaan pupuk organic dan an organic di DTA waduk Mrica

\begin{tabular}{|c|c|c|c|c|c|c|c|c|c|}
\hline \multirow{2}{*}{ Sub das } & \multicolumn{5}{|c|}{ Pupuk an organik (kg/ha) } & \multirow{2}{*}{ TOTAL } & \multicolumn{2}{|c|}{ Pupuk organik (kg/ha) } & \multirow{2}{*}{ TOTAL } \\
\hline & Urea & TSP & $\mathrm{KCL}$ & ZA & Ponska & & $\begin{array}{c}\text { Pupuk } \\
\text { kandang }\end{array}$ & Bokashi & \\
\hline Lumajang & 250.0 & 91.7 & 75.0 & & & 416.7 & 50.0 & & 50.0 \\
\hline $\begin{array}{l}\text { Serayu } \\
\text { Tengah }\end{array}$ & 137.5 & 56.7 & 45.0 & & & 239.2 & 516.7 & & 516.7 \\
\hline Mrawu & 41.7 & 38.0 & 102.5 & 100.0 & 70.0 & 352.2 & $5,826.4$ & 77.5 & $5,903.9$ \\
\hline Serayu Hulu & 25.0 & 75.0 & & & & 100.0 & $2,700.0$ & & $2,700.0$ \\
\hline Tulis & 65.8 & 110.7 & & 300.0 & 50.0 & 526.5 & $2,200.0$ & & $2,200.0$ \\
\hline Begaluh & 208.3 & 87.5 & 75.0 & & & 370.8 & 500.0 & & 500.0 \\
\hline TOTAL & 728.3 & 459.5 & 297.5 & 400.0 & 120.0 & $2,005.4$ & $11,793.0$ & 77.5 & $11,870.5$ \\
\hline
\end{tabular}

Sumber : Data Primer (Agustus 2010) 
Berdasarkan kemampuan mengikat nutrien $P$, tanah di kawasan DTA waduk Mrica mempunyai retensi tanah (mampu mengikat $P$ tanah) yang cukup tinggi yaitu sebesar $66,7 \%$ (Tabel 5 ). Kandungan $P$ total di tanah di sub DAS Tulis paling tinggi diantara sub DAS lainnya (Mrawu, Serayu Hulu, Serayu Tengah, Begaluh dan Lumajang) yaitu $0.12 \%$. Retensi P paling tinggi terdapat di wilayah sub DAS Serayu hulu yaitu sebesar $87.4 \%$, kemudian Begaluh (84.2 \%), Mrawu, Serayu Tengah, Tulis, dan Lumajang (55\%) Tabel 5 ). Meskipun kemampuan retensi $P$ nya tinggi, namun dengan tingginya erosi yang terjadi menyebabkan nutrien $\mathrm{P}$ yang terikat dalam tanah ikut tertransport ke waduk dan terakumulasi dalam sedimen waduk sehingga sedimen waduk Mrica mengandung $P$ tinggi (Piranti, 2009).

Hasil perhitungan CE dari masing- masing penggunaan lahan dapat digunakan untuk memperkirakan total nutrien loading $\mathrm{P}$ ke waduk Mrica. Berdasarkan perhitungan tersebut dan dengan mempertimbangkan luasan lahan di kawasan DTA waduk Mrica maka total loading nutrien dari DTA ke waduk Mrica sebesar $11,526.11 \mathrm{~kg} / \mathrm{th}$ dan paling tinggi berturut-turut berasal dari sawah $(5,184.85 \mathrm{~kg} / \mathrm{th})$, tegalan $(2,743.10 \mathrm{~kg} / \mathrm{th}$, kebun perhutani $(1,865.06 \mathrm{~kg} / \mathrm{th}$, pemukiman $(1,179.20 \mathrm{~kg} / \mathrm{th}$ dan hutan campur (554.50 kg/th) (Tabel 5). Berdasarkan persentase luasan masingmasing area penggunaan lahan tersebut meskipun persentasi area sawah lebih kecil dibandingkan luasan area tegalan dan kebun perhutani, namun karena coefficient export nutrien yang besar maka akan menghasilkan loading yang paling besar juga (Gambar 5).

Tabel 5. Kandungan P total tanah di DTA waduk Mrica dan retensi tanah

\begin{tabular}{clcc}
\hline Nomor & \multicolumn{1}{c}{ SUB DAS } & P tanah total (\%) & Retensi P tanah (\%) \\
\hline 1 & Merawu & 0.08 & 59.2 \\
2 & Tulis & 0.12 & 57.1 \\
3 & Lumajang & 0.06 & 55.0 \\
4 & Begaluh & 0.08 & 84.2 \\
5 & Serayu Hulu & 0.09 & 87.4 \\
6 & Serayu Tengah & 0.06 & 57.5 \\
\hline
\end{tabular}

Tabel6. Perhitungan total loading $\mathrm{P}$ dari masing-masing landuse dan Load allocation (LA) waduk Mrica

\begin{tabular}{|c|c|c|c|c|c|c|}
\hline Landuse & $\begin{array}{l}\text { CE DTA } \\
\text { waduk } \\
\text { Mrica* }\end{array}$ & $\begin{array}{c}\text { Luas } \\
\text { area }\end{array}$ & $\begin{array}{l}\text { Loading P } \\
\text { dari landuse }\end{array}$ & $\begin{array}{c}\text { Total Loading } \\
P \text { dari DTA }\end{array}$ & $\begin{array}{l}\text { Retens } \\
\text { tanah }\end{array}$ & $\begin{array}{c}\text { Load Allocation } \\
\text { (LA) ke } \\
\text { waduk Mrica }\end{array}$ \\
\hline & $\mathrm{kg} / \mathrm{ha} / \mathrm{th}$ & ha & (kg/th) & (kg/th) & & (kg/tahun) \\
\hline Kebun perhutani & 64.97 & 28707 & $1,865,057.24$ & $11,526,706.14$ & 0.67 & $3,833,587.70$ \\
\hline Tegalan & 76.20 & 35999 & $2,743,063.27$ & & & \\
\hline Sawah & 259.80 & 19957 & $5,184,857.40$ & & & \\
\hline Pemukiman & 146.25 & 8063 & $1,179,190.61$ & & & \\
\hline Hutan campur & 71.76 & 7728 & $554,537.62$ & & & \\
\hline TOTAL & 618.97 & 100,454 & $11,526,706.14$ & & & \\
\hline
\end{tabular}

Sumber : Data Primer (Mei - Juli 2010) 


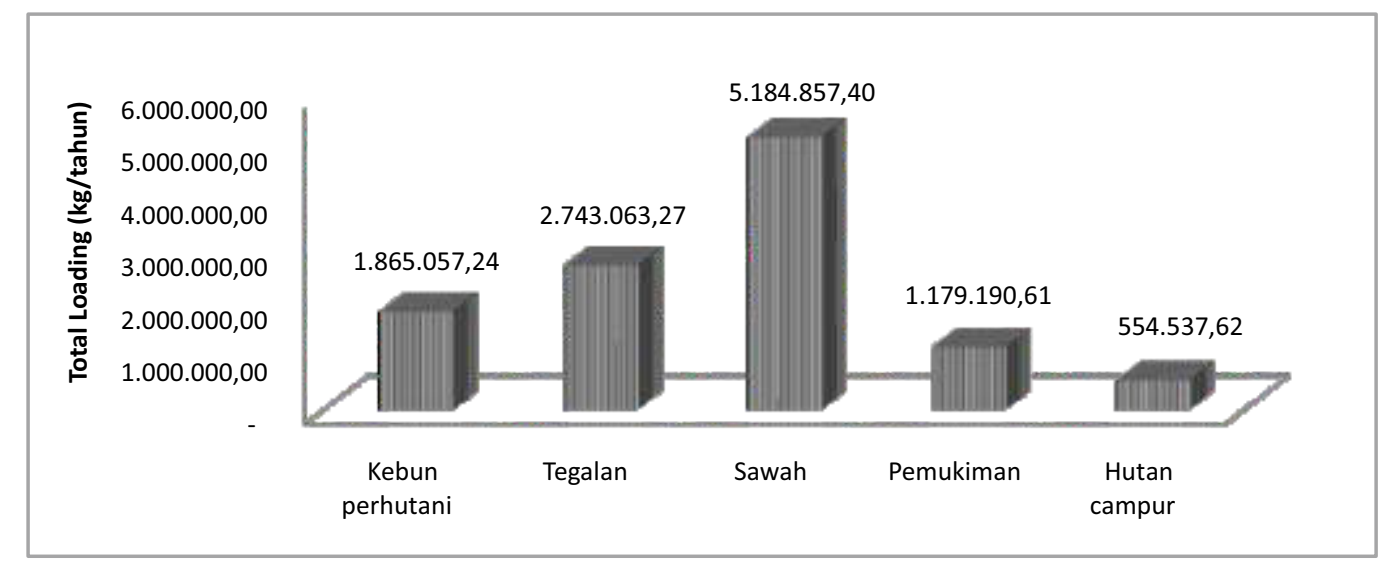

Gambar 5. Total loading dari masing-masing landuse

Hasil kajian nilai CE dari masingmasing penggunaan lahan yang ada di DTA waduk Mrica dan berdasarkan luas area masing-masing penggunaan lahan, maka hasil perhitungan total $\mathrm{P}$ loading dari DTA ke waduk Mrica sebesar 11,526.71 kg/tahun (nilai tersebut jika semua P yang ada di DTA ditransport seluruhnya ke waduk). Namun dengan kemampuan tanah-tanah di DTA mengikat $P$ (Retensi $P$ ) sebesar $66.74 \%$ maka beban nutrien yang masuk ke waduk (LA) menjadi sebesar 3,833.59 kg/tahun (Tabel 6.).

Besarnya beban LA ditambah dengan banyaknya nutrien yang telah mampu dikelola dalam program manajemen waduk tersebut atau disebut MOS (Margin of safety) maka akan mencerminkan besarnya TMDL waduk tersebut. Total Maximum Daily Load (TMDL) adalah perkiraan jumlah nutrien minimum yang mampu diasimilasi oleh sistem waduk tanpa menimbulkan terganggunya kualitas air untuk kehidupan organisme dan manusia yang memanfaatkan. Perhitungan TMDL tersebut dapat mencerminkan kondisi kualitas air saat ini. Berdasarkan hasil penelitian tahun pertama (2009), status trofik waduk Mrica berada pada status mesotrofik menuju eutrofik dengan nutrien kriteria yang masih di bawah ambang batas perairan eutrofik yaitu berkisar antara TN $3.14-8.84 \mathrm{mg} / \mathrm{l}$ dan TP $0.3-0.8 \mathrm{mg} / \mathrm{l}$ dan konsentrasi klorofil sebesar $4.2-10.5 \mathrm{mg} / \mathrm{m}^{3}$ pada bulan MaretSeptember dan sebesar 11.2 - $23.7 \mathrm{mg} / \mathrm{m}^{3}$ pada bulan Oktober - Februari (Piranti, 2009). Berdasarkan konsentrasi klorofilnya pada saat tertentu (Oktober - Februari) kondisi waduk Mrica berada pada fase eutrofik. Florida Lakewatch (2000) menyatakan bahwa perairan yang mengandung klorofil $>25 \mathrm{mg} / \mathrm{m}^{3}$ sudah mengganggu kehidupan organisme perairan lainnya. Oleh karena itu pada saat penelitian ini dilakukan pada musim penghujan kondisi waduk Mrica sudah mendekati fase hipereutrofik.Danau secara alami akan mengalami perkembangan status trofik dari oligotrofik menuju ke tingkat eutrofik, namun membutuhkan waktu yang sangat lama bahkan bisa mencapai ratusan tahun (Horne \& Goldman, 1994). Berdasarkan pernyataan tersebut, apabila ditinjau dari umur waduk yang baru 28 tahun maka waduk Mrica termasuk perairan yang mengalami kondisi eutrofik yang dipercepat akibat aktivitas manusia (cultural eutrophication). Untuk mengatasi masalah tersebut maka dapat dilakukan metode pengelolaan dengan menggunakan pembatasan besarnya nutrien loading yang masuk ke waduk Mrica baik dari sumber point sources maupun non point sources.

Perhitungan total nutrien yang ditransport dari DTA menuju ke waduk ternyata total loading nutrien yang bersumber dari non point sources sebesar 11,526,706.14 kg/th (Tabel 6). Berdasarkan perhitungan soil retention diperoleh kemampuan tanah-tanah yang ada di kawasan DTA waduk Mrica dalam mengikat nutrien adalah sebesar 0.67 yang berarti bahwa nutrien yang terkandung di dalam tanah di kawasan DTA waduk Mrica sebanyak $67 \%$ dapat diikat oleh tanah dan sisanya sebanyak $33 \%$ ditransport menuju ke waduk sebagai LA(Load allocation) atau sebesar 3,833,587.70 kg/tahun.

Margin of safety (MOS) merupakan 
perkiraan besarnya polutan yang telah mampu dikelola dalam program manajemen yang sedang diterapkan. Program pengelolaan nutrien dapat secara fisik maupun khemis (Harper, 1982). Secara fisik dapat dilakukan dengan cara memberi aerasi sehingga terjadi pelepasan nutrien nitrogen dari sedimen melalui proses nitrifikasi dan denitrifikasi menjadi bentuk an organik yang dapat langsung digunakan untuk metabolisme organisme waduk. Pengelolaan polutan nutrien dapat dilakukan juga secara kimia dengan cara memberi alumunium coagulant untuk mengikat nutrien P perairan. Untuk kasus waduk Mrica selama ini belum pernah dilakukan usaha mengurangi besarnya polutan terutama polutan nutrien menggunakan kedua cara tersebut (PT. Indonesia Power, Personal komunikasi).

Fungsi waduk Mrica sebagai PLTA dalam operasionalnya menggunakan sejumlah air dengan debit tertentu untuk menggerakkan 3 turbin untuk produksi listrik yang dikelola oleh PT. Indonesia Power UBP Mrica. Kehilangan air yang keluar melalui power intake yang digunakan untuk produksi listrik dapat secara langsung mengurangi kandungan nutrien dalam kolom air. Perkiraan banyaknya nutrien yang hilang akibat operasional waduk tersebut adalah sebesar 1,147,271.26 kg/tahun (Tabel 7).

Upaya mempertahankan fungsi waduk sebagai PLTA maka secara periodik di waduk Mrica dilakukan kegiatan flushing yang bertujuan untuk mempertahankan volume efektif waduk. Flushing merupakan bagian dari pola operasional waduk dengan melakukan penggelontoran waduk melalui drawdown culvet yang bertujuan untuk membuang sedimen waduk yang menutupi pintu power intake yang mengganggu dalam proses produksi listrik. Flushing ini sangat berpengaruh terhadap siklus nutrien di waduk karena lapisan air di hipolimnion yang mengandung nutrien tinggi terbuang keluar waduk. Total nutrien yang mampu dibuang dari kegiatan flushing ini sebesar $57.82 \mathrm{~kg} / \mathrm{th}$ (Tabel 7). Berdasarkan besarnya nutrien yang mampu terbuang melalui kedua kegiatan tersebut nilainya cukup besar yaitu $1,147,329.09 \mathrm{~kg} /$ tahun, maka secara tidak langsung dapat dikatakan sebagai Margin of Safety waduk dalam rangka pengelolaan nutrien penyebab eutrofikasi di waduk Mrica.

Tabel 7. Margin of Safety (MOS)V(Output nutrien dari Operasional PLTA dan kegiatan flushing

\begin{tabular}{|c|c|}
\hline Operasional rutin sebagai PLTA & Besarnya (kg/th) \\
\hline - Konsentrasi nutrient output (mg/l) & 0.57 \\
\hline - Debit output (m3/dt) & 64.25 \\
\hline - $\quad$ Total output nutrient (mg/dt) & 36885.01 \\
\hline - $\quad$ Total output nutrient (g/tahun) & $1,147,271,264.8$ \\
\hline - $\quad$ Total output nutrient (kg/tahun) & $1,147,271.26$ \\
\hline \multicolumn{2}{|l|}{ Flushing } \\
\hline - $\quad$ Rata-rata konsentrasi nutrien (mg/l) & 0.86 \\
\hline - $\quad$ Rata-rata volume flushing (m3/tahun) & $67,234.45$ \\
\hline - Rata-rata volume flushing(mg/th) & $57,821,630.91$ \\
\hline - Total output nutrien dalam flushing (kg/th) & 57.82 \\
\hline Total MOS (Output PLTA + Output Flushing) & $1,147,329.09$ \\
\hline
\end{tabular}

Beban nutrien yang berasal dari sumber point sources yang disebut dengan WLA (Waste load allocation) di waduk Mrica berasal dari budidaya ikan menggunakan karamba jaring apung (KJA). Total KJA yang ada di waduk Mrica sebanyak 710 petak dengan ukuran $6 \times 9 \times 1$ meter. Namun demikian KJA di waduk Mrica merupakan sistem budidaya yang tradisional dan tidak diberi pakan buatan (pelet). Berdasarkan personal komunikasi dengan beberapa petani ikan mengatakan bahwa pakan yang diberikan hanya berupa dedak dan tanaman air dan bahkan ada yang dibiarkan tanpa pakan atau hanya mengandalkan pakan alami yang berasal dari perairan waduk 
(plankton). Oleh karena itu, beban waduk terhadap input nutrien yang berasal dari KJA nilainya sangat kecil dan bisa diabaikan. Sumber WLA yang lain dapat juga berasal dari penduduk yang membuang limbah dan sampahnya domestiknya langsung ke waduk atau kegiatan industri yang melalui instalasi pengolah limbah (IPAL) dibuang langsung ke waduk. Kegiatan-kegiatan tersebut tidak didapatkan di waduk Mrica, sehingga Waste Load Allocation (WLA) waduk Mrica tidak significant dan dapat diabaikan (0 kg/tahun). Maka berdasarkan perhitungaan LA, WLA, dan MOS maka dapat ditentukan TMDL waduk Mrica adalah sebesar 4,980,916.78 kg/tahun (Tabel 8). Nilai TMDL tersebut sudah mendekati maksimal karena kondisi waduk saat ini pada saat-saat tertentu sudah mencapai fase eutrofik (konsentrasi klorofil mencapai $23.7 \mathrm{mg} / \mathrm{m} 3$. Oleh karena itu perlu dilakukan usaha untuk menurunkan beban nutrien (LA) ke waduk Mrica untuk memenuhi kualitas air yang diinginkan.

Tabel 8. Perhitungan TMDL waduk Mrica

\begin{tabular}{|c|c|c|c|c|c|c|}
\hline TMDL (kg/tahun) & $=$ & WLA & + & LA & + & MOS \\
\hline $4,980,916.78$ & & 0 & & $3,833,587.70$ & & $1,147,329.09$ \\
\hline
\end{tabular}

\section{Kesimpulan}

Hasil penelitian disimpulkan bahwa penggunaan lahan sawah paling tinggi dalam mentransport TP ke waduk, disusul dengan tegalan, kebun perhutani, pemukiman dan hutan.Pola operasional waduk sebagai PLTA dan kegiatan flushingmampu menurunkan beban nutrien yang masuk ke waduk.

\section{DAFTAR PUSTAKA}

Harper, D., 1992. Eutrofication of Freshwater. Chapman \& Hall. London. New York. Tokyo. Melbourne. Madras.

Hart, M.R.; Quin, B.F.; and Nguyen, M.L., 2004. Phosphorus Runoff from Agricultural Land and Direct Fertilizer Effects: A Review. Journal of Environmental Quality. 33: 1954 1972.

Horne, A.J. and Goldman, C.R., 1994. Lymnology. Second edition. McGraw Hill, Inc. New York.

Jeje, Y., 2006. Export Coefficients for Total Phosphorus, Total Nitrogen and Total Suspended Solids in the Southern Alberta Region. A Review of Literature. Her Majesty the Queen in right of the Province of Alberta, 2006.
McFarland, A.M.S. \& Hauek, L.M. 2001. Determining nutrient export coefficients \& source loadinguncertainty using in-stream monitoring data. Journal of the Amer. Water Res. Assoc. 37: 223-236.

PT. Indonesia Power, 2007. Data kelistrikan Jawa Bali dan Sedimen PLTA Waduk PB. Soedirman (Mrica). Makalah lokakarya "Konservasi bagian hulu DAS Serayu, DAS Tulis dan DAS Merawu". Unsoed Purwokerto.

Piranti, Agatha, Sudarmadji, Maryono, A.2009. Penentuan Nutrien Kriteria Waduk Mrica. Penelitian Hibah Bersaing Tahun ke 1. Unsoed. Purwokerto.

Subagiyo, A., 2006. Budidaya tanaman kentang dataran tinggi Dieng dengan dampak erosi minimal. Makalah Lokakarya Konservasi DAS Serayu Bagian Hulu. Unsoed Purwokerto. 